\title{
Gas-sensing properties and in-situ diffuse-reflectance Fourier-transform infrared spectroscopy study of diethyl ether adsorption and reactions on $\mathrm{SnO}_{2}$ film
}

\author{
Ning WANG ${ }^{1}$, KAIJIN HUANG ${ }^{1,2 *}$, JIAN SONG $^{1}$ \\ ${ }^{1}$ State Key Laboratory of Materials Processing and Die \& Mould Technology, Huazhong University of Science and \\ Technology, Wuhan 430074, P.R. China \\ ${ }^{2}$ State Key Laboratory of Advanced Technology for Materials Synthesis and Processing, Wuhan University of Technology, \\ Wuhan 430070, P.R. China
}

\begin{abstract}
Diethyl ether is a common industrial reagent and medical anesthetic. It is necessary to carry out real-time monitoring of this molecule due to its harmful effects on human health. In this paper, a highly sensitive diethyl ether $\mathrm{SnO}_{2}$ gas-sensing material has been prepared by a sol-gel method. The gas sensitivity was tested by a home-made gas-sensing equipment. The surface adsorption and reaction processes between the $\mathrm{SnO}_{2}$ gas-sensing film and the diethyl ether have been studied by in situ diffuse-reflectance Fourier-transform infrared spectroscopy (DRFT-IR) at different temperatures. The results show that the $\mathrm{SnO}_{2}$ gas-sensing material has high sensitivity to diethyl ether, and the lowest detection limit can reach 1 ppm. Furthermore, ethyl $\left(\mathrm{CH}_{3} \mathrm{CH}_{2} \bullet\right)$, oxoethyl $\left(\mathrm{CH}_{3} \mathrm{CH}_{2} \mathrm{O} \bullet\right)$, ethanol $\left(\mathrm{CH}_{3} \mathrm{CH}_{2} \mathrm{OH}\right)$, formaldehyde ( $\left.\mathrm{HCHO}\right)$, acetaldehyde $\left(\mathrm{CH}_{3} \mathrm{CHO}\right)$, ethylene $\left(\mathrm{C}_{2} \mathrm{H}_{4}\right), \mathrm{H}_{2} \mathrm{O}$ and $\mathrm{CO}_{2}$ surface species are formed during diethyl ether adsorption at different temperatures. A possible mechanism of the reaction process is discussed.
\end{abstract}

Keywords: gas sensitivity; $\mathrm{SnO}_{2}$ film; diethyl ether; in situ DRFT-IR

\section{Introduction}

Diethyl ether is a common organic solvent that is widely used in the fields of diesel engines, agriculture, and food, chemical, biological, pharmaceutical, and medical industries [1-4]. Due to its volatility, pungent odor, anesthetic effect, flammability, and explosive nature, diethyl ether creates a great risk to human health and safety. Prolonged inhalation of even low concentration can lead to headache, dizziness, proteinuria, disease of growth in quantity of red blood cells and even death [5-7]. Consequently, the maximum permissible concentration-time-weighted average (PC-TWA) and permissible concentrationshort-term exposure limit (PC-STEL) for diethyl ether are $300 \mathrm{mg} / \mathrm{m}^{3}(91 \mathrm{ppm})$ and $500 \mathrm{mg} / \mathrm{m}^{3}$ (151.1 ppm), respectively, in China [5]. Therefore, it is necessary to carry out real-time monitoring of this compound.

*E-mail: huangkaijin@hust.edu.cn
To date, many methods have been devised for the detection of diethyl ether at the ppm or ppb level. Gas chromatography (GC) [8], GC/MS [9], surface acoustic wave [10], gas test-tube [11], chemiluminescence (CL) and cataluminescence (CTL) methods $[9,12]$ have been used to detect ppm and/or ppb grade diethyl ether. However, these methods are associated with various disadvantages, being either expensive, or time-consuming, requiring complex experimental apparatus or large instrument volume, or involving toxic solvents or reagents [8-12]. On the other hand, gas sensors based on metal oxide semiconductors, like $\mathrm{SnO}_{2}$, $\mathrm{ZnO}$ and $\mathrm{Fe}_{2} \mathrm{O}_{3}$ have attracted much attention due to their unique features, such as low cost, high sensitivity, fast response, relative simplicity and portability [13-15].

It is well known that $\mathrm{SnO}_{2}$ is widely used as a gas-sensing material. Many literature reports [1621] have highlighted the excellent gas-sensing properties of $\mathrm{SnO}_{2}$. For example, Ohgaki et al. [16] reported that the sensitivities of a PLD-grown $\mathrm{SnO}_{2}$ 
sensor to $1000 \mathrm{ppm} \mathrm{NO}_{2}$ and $1 \% \mathrm{H}_{2}$ were 2 and 1 at $350{ }^{\circ} \mathrm{C}$, respectively. Liu et al. [17] reported that the sensitivities of an $\mathrm{SnO}_{2}$ sensor to $10 \mathrm{ppm}$, $20 \mathrm{ppm}, 30 \mathrm{ppm}, 40 \mathrm{ppm}$ and $50 \mathrm{ppm}$ ethanol were $18.8,33.3,42.7,51.8$ and 60.5 , respectively. He et al. [18] reported that the sensitivities of a porous $\mathrm{SnO}_{2}$ nanotube sensor to $100 \mathrm{ppm}$ ethanol and acetone were 130 and 126 at $200{ }^{\circ} \mathrm{C}$, respectively. Wang et al. [19] reported that the sensitivity of an $\mathrm{SnO}_{2}$ nanorod sensor to $1 \mathrm{ppm}$ triethylamine was 3.0 at $350{ }^{\circ} \mathrm{C}$. Hyodo et al. [20] reported that the sensitivity of a mesoporous $\mathrm{SnO}_{2}$ sensor to $1000 \mathrm{ppm} \mathrm{H}_{2}$ was 337 at $400{ }^{\circ} \mathrm{C}$. Huang et al. [21] reported that the sensitivity of an $\mathrm{SnO}_{2}$ nanotube sheet to $100 \mathrm{ppm} \mathrm{H}_{2}$ was 16.5 at $450{ }^{\circ} \mathrm{C}$.

To the best of our knowledge, there has been no literature report on the sensing of diethyl ether with $\mathrm{SnO}_{2}$ gas-sensing material, although many reports have been concerned with the sensing of diethyl ether with other materials [22-28]. For example, Wang et al. [22] studied the gas sensitivity of a P(St-AM)@Ag sensor and found that the gas sensitivity of about 3.12 was achieved at $16{ }^{\circ} \mathrm{C}$. The lowest concentration detection limit and the response/recovery times were not specified. Ren [23] studied the diethyl ether vaporsensing properties of $\mathrm{SnO}_{2}-0.005 \%$ palladium asbestos, $\mathrm{SnO}_{2}-0.005 \% \mathrm{CeO}_{2}$ and $\mathrm{ZnO}-0.05 \%$ rare earth oxide (REO) sensors. The results showed that the gas sensitivities $\left(I_{g} / I_{a}\right)$ were $3.2,0.33$ and 170 respectively, at a diethyl ether concentration of $0.05 \%$. Again, the lowest concentration detection limit and the response/recovery times were not specified. Slobodian et al. [24] reported diethyl ether vapor-sensing properties of various multiwalled carbon nanotube (MWCNT)-based sensors, specifically based on pure MWCNTs, oxidized MWCNTs, and sonicated MWCNTs. The gas sensitivities $\left(\left(\mathrm{R}_{\mathrm{g}}-\mathrm{R}_{\mathrm{a}}\right) / \mathrm{R}_{\mathrm{a}} \cdot 100 \%\right)$ were about $21 \%$, $28 \%$ and $2.6 \%$, respectively, at $25{ }^{\circ} \mathrm{C}$ at a volume concentration of $70.9 \%$. The response times were $90 \mathrm{~s}$ to $130 \mathrm{~s}$ and the recovery times were $200 \mathrm{~s}$ to $260 \mathrm{~s}$. Ma et al. [25] studied the diethyl ether vaporsensing properties of an $\mathrm{Ag} / \alpha-\mathrm{Fe}_{2} \mathrm{O}_{3}$ based sensor. The gas sensitivity was 3.0 at $260{ }^{\circ} \mathrm{C}$ and $100 \mathrm{ppm}$, and the response and the recovery times were $5 \mathrm{~s}$ and $6 \mathrm{~s}$, respectively. Zhao et al. [26] reported diethyl ether gas sensitivities of $\mathrm{SiC}$ films as 1.1 (at $50 \mathrm{ppm}$ ) and 1.3 (at $400 \mathrm{ppm}$ ) at $250{ }^{\circ} \mathrm{C}$. Aizawa et al. [27] reported diethyl ether gas sensitivity of a PP-HMDSO film as 4.5. Gui et al. [28] reported that the gas sensitivity of a $\mathrm{Pd}$ doped $\mathrm{WO}_{3}$ sensor to $2240 \mathrm{ppm}$ diethyl ether was about 10 .

In this study, $\mathrm{SnO}_{2}$ gas-sensing material has been prepared by sol-gel method and deployed for sensing of diethyl ether vapor. The adsorption and reactions on the $\mathrm{SnO}_{2}$ gas-sensing film have been studied by in situ diffuse reflectance Fouriertransform infrared spectroscopy.

\section{Experimental}

\subsection{Preparation and characterization of nano-SnO 2 powder}

Nano-SnO $\mathrm{S}_{2}$ powder was prepared by a sol-gel method. An aqueous solution of $\mathrm{SnCl}_{4}\left(0.5 \mathrm{~mol} \cdot \mathrm{L}^{-1}\right)$ was prepared by mixing $\mathrm{SnCl}_{4} \cdot 5 \mathrm{H}_{2} \mathrm{O} \quad(10.6242 \mathrm{~g})$ with distilled water $(60 \mathrm{~mL})$. An $\mathrm{NH}_{3} \cdot \mathrm{H}_{2} \mathrm{O}$ aqueous solution ( $3.5 \mathrm{~mol} \cdot \mathrm{L}^{-1}$ ) was added dropwise to the aqueous solution under stirring at $50{ }^{\circ} \mathrm{C}$ to $60{ }^{\circ} \mathrm{C}$, until the $\mathrm{pH}$ value of 2 to 3 was reached. The obtained solution was boiled at $55^{\circ} \mathrm{C}$ for $2 \mathrm{~h}$, during which the solution slowly turned into a turbid colloidal solution. After cooling down, the sol was collected from the solution by filtration and washed several times with distilled water and ethanol. After drying at $80{ }^{\circ} \mathrm{C}$ for $12 \mathrm{~h}$ in a drying oven, the obtained gel powders were ground in a mortar and calcined in a muffle furnace at $500{ }^{\circ} \mathrm{C}$ for $2 \mathrm{~h}$ to obtain nano- $\mathrm{SnO}_{2}$ powders. The nano-SnO $\mathrm{Sn}_{2}$ powders were examined by XRD and FESEM techniques. The results of XRD and FESEM showed that the nano- $\mathrm{SnO}_{2}$ powders had crystalline rutile structure consisting of spherical crystals with diameters of approximately $10 \mathrm{~nm}$ to $20 \mathrm{~nm}$. The detailed characterization of nano- $\mathrm{SnO}_{2}$ powder was given in our previous paper [29].

\subsection{Measurement of diethyl ether gas- sensing properties}

A gas-sensing paste was first obtained by grinding. For this purpose, the prepared $\mathrm{SnO}_{2}$ powder 
was mixed and ground with the appropriate amount of organic solution, and ball-milled in an agate mortar for $3 \mathrm{~h}$. A screen-printing technique was then used to print the paste onto an alumina substrate with pre-printed Au interdigital electrodes. Thereafter, the alumina substrate with the printed $\mathrm{SnO}_{2}$ paste $\left(60.0\right.$ wt. $\% \mathrm{SnO}_{2}, 21.24$ wt.\% terpineol, $10.62 \mathrm{wt} . \%$ butyl-carbitol-acetate, $3.54 \mathrm{wt} . \%$ di-nbutyl phthalate, 2.4 wt.\% ethylcellulose, 1.6 wt.\% Span $85,0.4$ wt. $\%$ butyrolactone, and 0.2 wt. $\%$ hydrogenated castor oil) were sintered at $550{ }^{\circ} \mathrm{C}$ for $3 \mathrm{~h}$. Finally, the alumina substrate with the printed $\mathrm{SnO}_{2}$ gas-sensing material was aged at $250{ }^{\circ} \mathrm{C}$ for 3 days in air to enhance the gas-sensing stability. The gas sensitivity of $\mathrm{SnO}_{2}$ film to diethyl ether was tested with our in-house-constructed equipment. A high throughput test platform for characterization of gas sensitivity was designed and established in our laboratory. The test platform has the advantages such as high throughput (36 test channels), large resistance measurement range (500 $\Omega$ to $100 \mathrm{M} \Omega$, and test error less than $5 \%$ ), accurate temperature control (within $1{ }^{\circ} \mathrm{C}$ ), and friendly interface. The gas-sensing material testing platform consisted of a computer, temperature control module, gas path control module, signal conditioning module, and test chamber. The detailed procedure was described in the literature [30]. Gas sensitivity is defined in this paper as $\mathrm{S}=\mathrm{R}_{\mathrm{a}} / \mathrm{R}_{\mathrm{g}}[25,31]$, where $R_{a}$ and $R_{g}$ are the resistances of a sensor in air and in a test gas, respectively.

\subsection{In-situ DRFT-IR study}

The adsorption and reactions of diethyl ether on $\mathrm{SnO}_{2}$ film were studied by in-situ diffuse-reflectance Fourier-transform infrared spectroscopy (DRFT-IR). All spectra were recorded at $350{ }^{\circ} \mathrm{C}$ to $400{ }^{\circ} \mathrm{C}$ on a VERTEX 70 FT-IR Spectrometer (Bruker) equipped in a liquid-nitrogen-cooled mercury cadmium telluride detector in a range of $3800 \mathrm{~cm}^{-1}$ to $1000 \mathrm{~cm}^{-1}$ and a diffuse-reflectance accessory containing an environment and temperature controlled reflectance cell equipped with $\mathrm{KBr}$ windows. The spectra with a resolution of $4 \mathrm{~cm}^{-1}$ were obtained by averaging 128 scans and analyzed using OPUS software.
Further details can be found in the literature [32]. A gas stream $\left(30 \mathrm{~mL} \cdot \mathrm{min}^{-1}\right)$ of $200 \mathrm{ppm}$ diethyl ether was introduced into the cell at $350{ }^{\circ} \mathrm{C}$, $380{ }^{\circ} \mathrm{C}$, or $400{ }^{\circ} \mathrm{C}$, and the spectra were recorded on the pre-treated sample. It should be pointed out that oxygen existed in the 200 ppm diethyl ether during the DRFT-IR test because the dry synthetic air $\left(20 \% \mathrm{O}_{2}+80 \% \mathrm{~N}_{2}\right)$ was used as the filling gas of the diethyl ether. In addition, according to [33], the initial auto-oxidation temperature of diethyl ether was approximately $389 \mathrm{~K}$ and thermal decomposition occurred under an oxygen atmosphere at low temperature. The oxidation reaction pathway of diethyl ether with oxygen was found to occur in three stages: (1) absorption of oxygen and generation of peroxide by diethyl ether; (2) free radical generation by thermal decomposition and (3) complex oxidation reaction by free radicals. So, the catalytic reactions of diethyl ether on the surface of $\mathrm{SnO}_{2}$ and the thermal decomposition reactions of diethyl ether in the measuring cell existed during the DRFT-IR test. Independently of the kind of reaction, the final reaction products in an atmosphere containing oxygen, were $\mathrm{CO}_{2}$ and $\mathrm{H}_{2} \mathrm{O}$. Therefore, the products identified by the DRFT-IR spectra should be the comprehensive products of catalytic reactions and thermal decomposition reactions of diethyl ether.

\section{Results and discussion}

\subsection{Gas-sensing properties of $\mathrm{SnO}_{2}$ sen- sor arrays}

Fig. 1 shows a plot of the effect of operating temperature on the gas sensitivity of $\mathrm{SnO}_{2}$ sensor to $200 \mathrm{ppm}$ diethyl ether. The gas sensitivity increases with increasing operating temperature, and reaches a maximum value of 113.03 at $380{ }^{\circ} \mathrm{C}$. This phenomenon is very common and can be found in many literature reports [32, 34, 35]. The reason is that the adsorption mode of oxygen molecules changes from physisorption at lower temperature to chemisorption at higher temperature [32].

The amount of chemically adsorbed diethyl ether increases with increasing of working temperature from room temperature. The more 


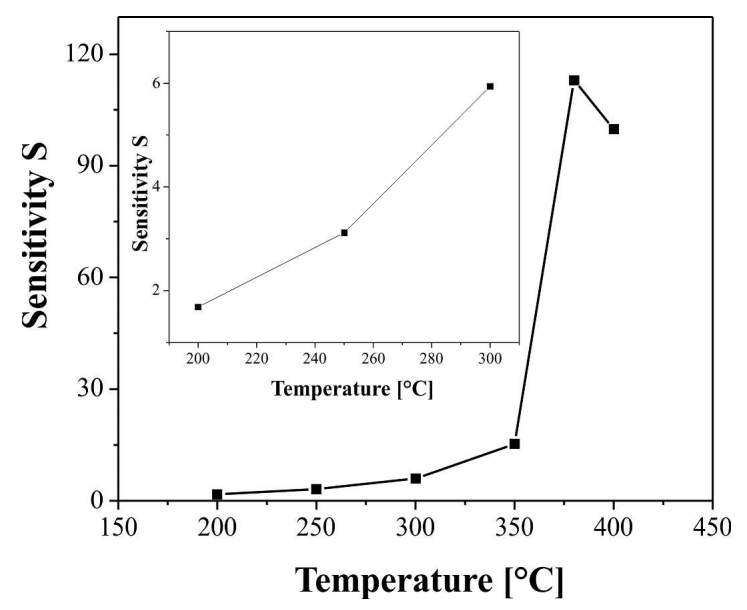

Fig. 1. Effect of operating temperature on the gas sensitivity of the $\mathrm{SnO}_{2}$ sensor to $200 \mathrm{ppm}$ diethyl ether.

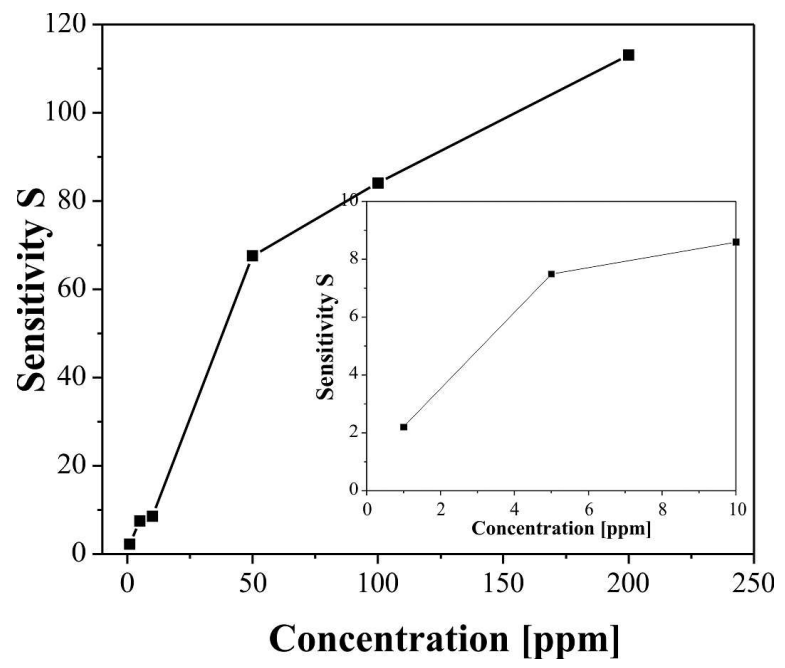

Fig. 2. Gas sensitivity of the $\mathrm{SnO}_{2}$ sensor vs. diethyl ether concentration ( $1 \mathrm{ppm}$ to $200 \mathrm{ppm}$ ) at $380{ }^{\circ} \mathrm{C}$.

the chemically adsorbed diethyl ether, the more negative oxygen ions consumed, the more free electrons are produced, and the more the resistance of the gas-sensing material decreases. So, the gas sensitivity increases with the increase of working temperature. The adsorption reaches a dynamic equilibrium of absorption-desorption at a certain temperature $\left(380{ }^{\circ} \mathrm{C}\right.$ in the present case) because the chemisorption is an exothermic reaction. If the working temperature is increased further, the reactants begin to desorb in large quantities [32].
Hence, beyond $380{ }^{\circ} \mathrm{C}$, the amount of absorbed diethyl ether molecules will progressively decrease, and the balance will move toward desorption, resulting in a decreased gas sensitivity above this temperature (Fig. 1). The reactions of adsorption of $\mathrm{O}_{2}$ and diethyl ether during this process may be described as follows [36]:

$$
\begin{gathered}
\mathrm{O}_{2}(\mathrm{~g}) \Longleftrightarrow \mathrm{O}_{2}(\text { ads }) \\
\mathrm{O}_{2}(\text { ads })+\mathrm{e}^{-} \Longleftrightarrow \mathrm{O}_{2}^{-}(\text {ads }) \\
\mathrm{O}_{2}^{-}(\text {ads })+\mathrm{e}^{-} \Longleftrightarrow 2 \mathrm{O}^{-}(\text {ads }) \\
\mathrm{C}_{2} \mathrm{H}_{5} \mathrm{OC}_{2} \mathrm{H}_{5}(\text { ads })+12 \mathrm{O}^{-}(\text {ads }) \\
\Longleftrightarrow 5 \mathrm{H}_{2} \mathrm{O}+4 \mathrm{CO}_{2}+12 \mathrm{e}^{-}
\end{gathered}
$$

Fig. 2 shows the relationship between the gas sensitivity of the $\mathrm{SnO}_{2}$ sensor and the concentration of diethyl ether. As shown in Fig. 2, the gas sensitivity is dependent on the concentration of diethyl ether from $1 \mathrm{ppm}$ to $200 \mathrm{ppm}$, and increases with the increase of the concentration at the optimal operating temperature of $380^{\circ} \mathrm{C}$.

This phenomenon is also very common and can be found in many literature reports $[34,37]$. The gas sensitivity of the $\mathrm{SnO}_{2}$ sensor is 2.19 to $1 \mathrm{ppm}$ at $380{ }^{\circ} \mathrm{C}$, and increases to 113.03 to $200 \mathrm{ppm}$ at $380{ }^{\circ} \mathrm{C}$. That is to say, the lowest detection limit of the $\mathrm{SnO}_{2}$ sensor to diethyl ether can reach $1 \mathrm{ppm}$, which meets the demand for real-time monitoring of this molecule [5]. The high gas sensitivity of the $\mathrm{SnO}_{2}$ sensor may be related to its large specific surface area of $51.6819 \mathrm{~m}^{2} \cdot \mathrm{g}^{-1}$ [29]. As an n-type semiconductor, the $\mathrm{SnO}_{2}$ surface forms an electron depletion layer when negative oxygen ions are adsorbed thereon at the working temperature. This increases the surface potential barrier and the resistance. When diethyl ether molecules reach the gas-sensing material surface, the adsorbed negative oxygen ions are consumed and free electrons are produced. Hence, the resistance of the material is reduced. In the absence of diethyl ether, the resistance is recovered. The change in resistance thus provides a sensitive means of detection. 


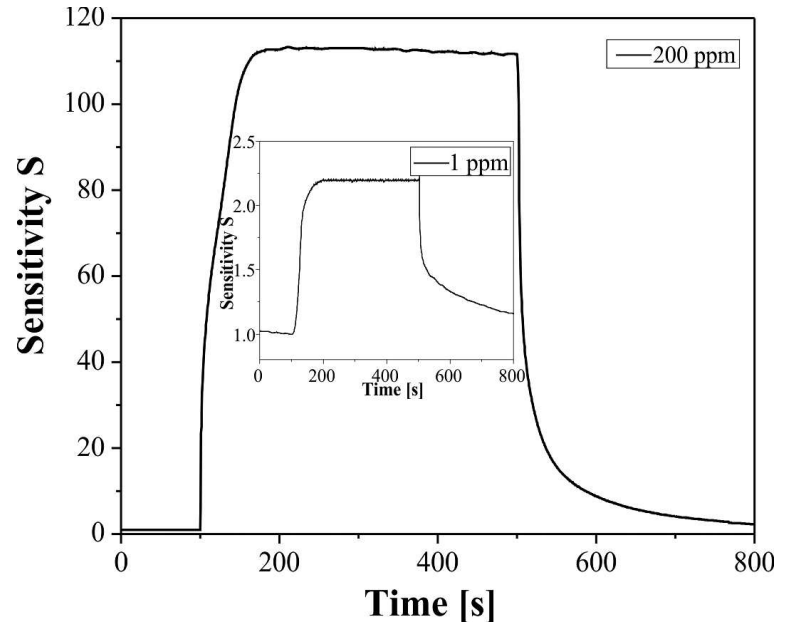

Fig. 3. Response and recovery curve of the $\mathrm{SnO}_{2}$ sensor to $200 \mathrm{ppm}$ diethyl ether at $380{ }^{\circ} \mathrm{C}$ (Inset: corresponding curve at $1 \mathrm{ppm}$ diethyl ether).

In addition, the response and the recovery times of the $\mathrm{SnO}_{2}$ sensor to $1 \mathrm{ppm}$ and $200 \mathrm{ppm}$ diethyl ether are illustrated in Fig. 3. From Fig. 3, it can be seen that these parameters are $35 \mathrm{~s}$ and $125 \mathrm{~s}$, respectively, at $1 \mathrm{ppm}$ diethyl ether, and $46 \mathrm{~s}$ and $63 \mathrm{~s}$ at $200 \mathrm{ppm}$ diethyl ether, respectively.

\subsection{In-situ DRFT-IR study}

Fig. 4 to Fig. 6 show the DRFT-IR spectra obtained at different temperatures $\left(350{ }^{\circ} \mathrm{C}, 380{ }^{\circ} \mathrm{C}\right.$, and $400{ }^{\circ} \mathrm{C}$ ) at $200 \mathrm{ppm}$ of diethyl ether. The IR assignments of diethyl ether adsorption on the $\mathrm{SnO}_{2}$ film and thermal decomposition of ethyl ether at different temperatures are given in Table 1 [38-53].

Fig. 4 shows the DRFT-IR spectra of 200 ppm diethyl ether adsorption on $\mathrm{SnO}_{2}$ film and thermal decomposition of ethyl ether at $350{ }^{\circ} \mathrm{C}$. The absorption peaks at $v=3768 \mathrm{~cm}^{-1}, 3586 \mathrm{~cm}^{-1}$ are the stretching vibration of $\mathrm{H}_{2} \mathrm{O}$ molecule $v\left(\mathrm{H}_{2} \mathrm{O}\right)$; that at $v=2356 \mathrm{~cm}^{-1}$ is a stretching vibration of $\mathrm{CO}_{2}$, the intensity of $\mathrm{CO}_{2}$ peak after $10 \mathrm{~min}$ is higher than that after $3 \mathrm{~min}$. It indicates that the production of $\mathrm{CO}_{2}$ progressively increased. And those at $v=1768 \mathrm{~cm}^{-1}$, $1715 \mathrm{~cm}^{-1}$ can be assigned as a $\mathrm{C}=\mathrm{O}$ stretching vibration $v(\mathrm{C}=\mathrm{O})$ of aldehyde ( $\mathrm{HCHO}$ or $\left.\mathrm{CH}_{3} \mathrm{CHO}\right)$. The absorption band at $v=1681 \mathrm{~cm}^{-1}$

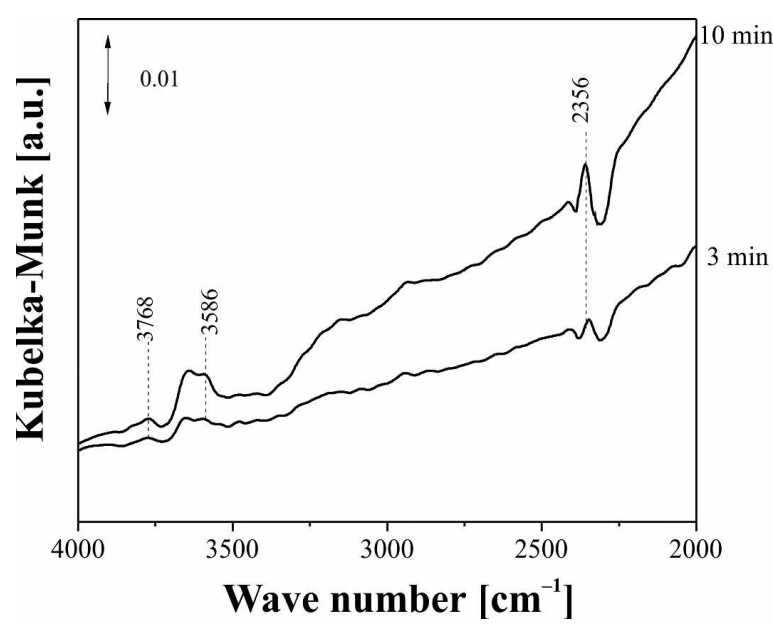

(a)

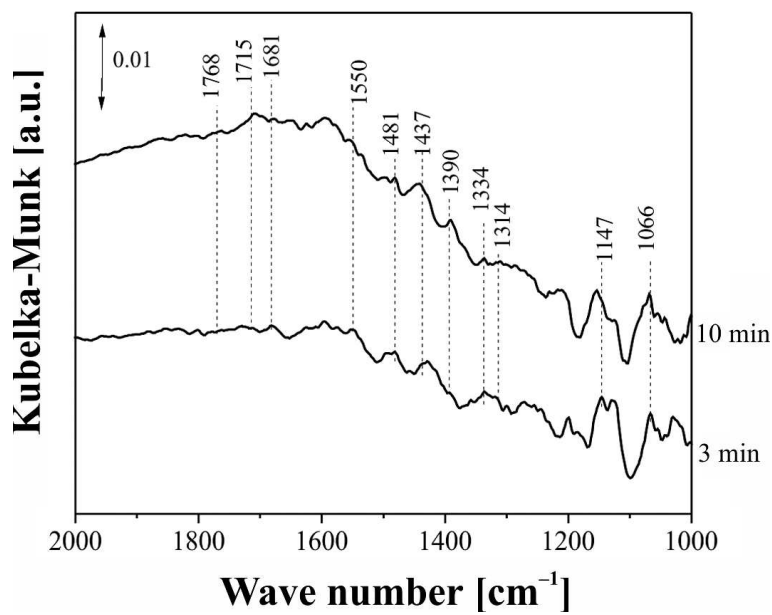

(b)

Fig. 4. DRFT-IR spectra of 200 ppm diethyl ether adsorption on an $\mathrm{SnO}_{2}$ film and thermal decomposition of ethyl ether at $350{ }^{\circ} \mathrm{C}$ : (a) $4000 \mathrm{~cm}^{-1}$ to $2000 \mathrm{~cm}^{-1}$, (b) $2000 \mathrm{~cm}^{-1}$ to $1000 \mathrm{~cm}^{-1}$.

is a $\mathrm{C}=\mathrm{C}$ stretching vibration $v(\mathrm{C}=\mathrm{C})$. The band at $v=1550 \mathrm{~cm}^{-1}$ is the deformation vibration of a $\mathrm{H}_{2} \mathrm{O}$ molecule $\delta\left(\mathrm{H}_{2} \mathrm{O}\right)$. And those at $v=1481 \mathrm{~cm}^{-1}$ and $1390 \mathrm{~cm}^{-1}$ are $\mathrm{CH}_{2}$, $\mathrm{CH}_{3}$ deformation vibrations $\delta\left(\mathrm{CH}_{2}\right), \delta\left(\mathrm{CH}_{3}\right)$, respectively. These bands can be attributed to the intermediate products ethyl $\left(\mathrm{CH}_{3} \mathrm{CH}_{2} \bullet\right)$ and oxoethyl $\left(\mathrm{CH}_{3} \mathrm{CH}_{2} \mathrm{O} \bullet\right)$. The absorption peaks at $v=1437 \mathrm{~cm}^{-1}$ and $1314 \mathrm{~cm}^{-1}$ are deformation vibrations $\delta\left(\mathrm{CH}_{2}\right)$ and $\delta(\mathrm{CH})$ of ethylene $\left(\mathrm{C}_{2} \mathrm{H}_{4}\right)$ molecule, and this means that $\mathrm{C}_{2} \mathrm{H}_{4}$ has been produced. That at $v=1334 \mathrm{~cm}^{-1}$ 
Table 1. IR assignments of diethyl ether adsorption on an $\mathrm{SnO}_{2}$ film and thermal decomposition of ethyl ether at different temperatures.

\begin{tabular}{lcccc}
\hline Surface species & $\begin{array}{c}\text { Wave number } \\
{\left[\mathrm{cm}^{-1}\right]\left(3500^{\circ} \mathrm{C}\right)}\end{array}$ & $\begin{array}{c}\text { Wave number } \\
{\left[\mathrm{cm}^{-1}\right]\left(380{ }^{\circ} \mathrm{C}\right)}\end{array}$ & $\begin{array}{c}\text { Wave number } \\
{\left[\mathrm{cm}^{-1}\right]\left(400{ }^{\circ} \mathrm{C}\right)}\end{array}$ & Literature \\
\hline \hline$v\left(\mathrm{H}_{2} \mathrm{O}\right)$ & $3768 / 3586$ & $3768 / 3563 / 3210$ & $3769 / 3513$ & {$[38]$} \\
$v\left(\mathrm{CO}_{2}\right)$ & 2356 & 2347 & 2347 & {$[39]$} \\
$v(\mathrm{C}=\mathrm{O})$ & $1768 / 1715$ & $1781 / 1723$ & $1760 / 1710$ & {$[40]$} \\
$v(\mathrm{C}=\mathrm{C})$ & 1681 & 1647 & 1649 & {$[40,41]$} \\
$\delta\left(\mathrm{H}_{2} \mathrm{O}\right)$ & 1550 & $3642 / 1591$ & 1586 & {$[42-44]$} \\
$\delta_{\mathrm{a}}\left(\mathrm{CH}_{2}\right)$ & 1481 & 1490 & 1523 & {$[45-49]$} \\
$\delta_{\mathrm{b}}\left(\mathrm{CH}_{2}\right)$ & 1437 & 1409 & 1467 & {$[45-49]$} \\
$\delta\left(-\mathrm{CH}_{3}\right)$ & 1390 & 1386 & 1372 & {$[42,43]$} \\
$v(\mathrm{C}-\mathrm{CHO})$ & 1334 & 1462 & 1426 & {$[42,43]$} \\
$\delta(\mathrm{OH})$ & - & 1336 & 1329 & {$[42,43]$} \\
$\delta(\mathrm{CH})$ & 1314 & 1293 & 1218 & {$[50,51]$} \\
$v(\mathrm{C}-\mathrm{O}-\mathrm{C})$ & 1147 & 1147 & 1164 & {$[41]$} \\
$v(\mathrm{C}-\mathrm{C})$ & 1066 & 1052 & 1091 & {$[50-52]$} \\
$v(\mathrm{C}-\mathrm{O})$ & - & 1026 & 1040 & {$[45,53]$} \\
\hline
\end{tabular}

Note:

$\delta_{\mathrm{a}}\left(\mathrm{CH}_{2}\right): \mathrm{CH}_{3} \mathrm{CH}_{2} \bullet / \mathrm{CH}_{3} \mathrm{CH}_{2} \mathrm{O} \bullet$

$\delta_{\mathrm{b}}\left(\mathrm{CH}_{2}\right): \mathrm{CH}_{2}=\mathrm{CH}_{2}$

is a $\mathrm{C}-\mathrm{CHO}$ stretching vibration $\mathrm{v}(\mathrm{C}-\mathrm{CHO})$, and it suggests that $\mathrm{HCHO}$ and $\mathrm{CH}_{3} \mathrm{CHO}$ have been produced $[9,48-54]$. The absorption peak at $v=1147 \mathrm{~cm}^{-1}$ is a $\mathrm{C}-\mathrm{O}-\mathrm{C}$ stretching vibration $v(\mathrm{C}-\mathrm{O}-\mathrm{C})$ of diethyl ether, and this means that diethyl ether molecule has been absorbed on the surface. And that at $v=1066 \mathrm{~cm}^{-1}$ is a $\mathrm{C}-\mathrm{C}$ stretching vibration $v(\mathrm{C}-\mathrm{C})$.

Possible equations describing the process may be written as follows [54]:

$\mathrm{CH}_{3} \mathrm{CH}_{2} \mathrm{OCH}_{2} \mathrm{CH}_{3}(\mathrm{~g}) \rightarrow \mathrm{CH}_{3} \mathrm{CH}_{2} \mathrm{OCH}_{2} \mathrm{CH}_{3}$ (ads)

$$
\begin{gathered}
\mathrm{CH}_{3} \mathrm{CH}_{2} \mathrm{OCH}_{2} \mathrm{CH}_{3}(\mathrm{ads})+\mathrm{SnO}_{2} \\
\rightarrow \mathrm{CH}_{3} \mathrm{CH}_{2} \bullet+\mathrm{CH}_{3} \mathrm{CH}_{2} \mathrm{O} \bullet+\mathrm{SnO}_{2} \\
\mathrm{CH}_{3} \mathrm{CH}_{2} \bullet \rightarrow \mathrm{C}_{2} \mathrm{H}_{4}+\mathrm{H} \bullet \\
\mathrm{CH}_{3} \mathrm{CH}_{2} \mathrm{O} \bullet \rightarrow \mathrm{CH}_{3} \mathrm{CHO}+\mathrm{H} \bullet \\
\mathrm{CH}_{3} \mathrm{CH}_{2} \mathrm{O} \bullet \rightarrow \mathrm{HCHO}+\mathrm{CH}_{3} \bullet \\
\mathrm{C}_{2} \mathrm{H}_{4}+6 \mathrm{O}^{-} \rightarrow 2 \mathrm{H}_{2} \mathrm{O}+2 \mathrm{CO}_{2}+6 \mathrm{e}^{-}
\end{gathered}
$$

$$
\begin{gathered}
\mathrm{CH}_{3} \mathrm{CHO}+5 \mathrm{O}^{-} \rightarrow 2 \mathrm{H}_{2} \mathrm{O}+2 \mathrm{CO}_{2}+5 \mathrm{e}^{-} \\
\mathrm{HCHO}+2 \mathrm{O}^{-} \rightarrow \mathrm{H}_{2} \mathrm{O}+\mathrm{CO}_{2}+2 \mathrm{e}^{-}
\end{gathered}
$$

Fig. 5 shows DRFT-IR spectra of $200 \mathrm{ppm}$ diethyl ether adsorption on the $\mathrm{SnO}_{2}$ film and thermal decomposition of ethyl ether at the optimal temperature of $380{ }^{\circ} \mathrm{C}$. Compared to Fig. 4, the peak intensities of $\mathrm{CO}_{2}$ are enhanced and some new peaks are apparent. The peaks at $v=3768 \mathrm{~cm}^{-1}, 3563 \mathrm{~cm}^{-1}$ and $3210 \mathrm{~cm}^{-1}$ are the stretching vibration of $\mathrm{H}_{2} \mathrm{O}$ molecule $v\left(\mathrm{H}_{2} \mathrm{O}\right)$, those at $v=3642 \mathrm{~cm}^{-1}$ and $1591 \mathrm{~cm}^{-1}$ are the deformation vibration of $\mathrm{H}_{2} \mathrm{O}$ molecule $\delta\left(\mathrm{H}_{2} \mathrm{O}\right)$. And that at $v=2347 \mathrm{~cm}^{-1}$ is a $\mathrm{CO}_{2}$ stretching vibration $v\left(\mathrm{CO}_{2}\right)$. The intensity of the $\mathrm{CO}_{2}$ peak after $10 \mathrm{~min}$, at $380{ }^{\circ} \mathrm{C}$, is also higher than that after $3 \mathrm{~min}$. The absorption peaks at $v=$ $1781 \mathrm{~cm}^{-1}$ and $1723 \mathrm{~cm}^{-1}$ are $\mathrm{C}=\mathrm{O}$ stretching vibration $v(\mathrm{C}=\mathrm{O})$ of an aldehyde ( $\mathrm{HCHO}$ or $\left.\mathrm{CH}_{3} \mathrm{CHO}\right)$. And that at $v=1647 \mathrm{~cm}^{-1}$ is a $\mathrm{C}=\mathrm{C}$ stretching vibration $v(\mathrm{C}=\mathrm{C})$. The peaks at $v=1490 \mathrm{~cm}^{-1}$ and $1386 \mathrm{~cm}^{-1}$ are the $\mathrm{CH}_{2}$, $\mathrm{CH}_{3}$ deformation vibrations $\delta\left(\mathrm{CH}_{2}\right), \delta\left(\mathrm{CH}_{3}\right)$, respectively. These features can be attributed to the 


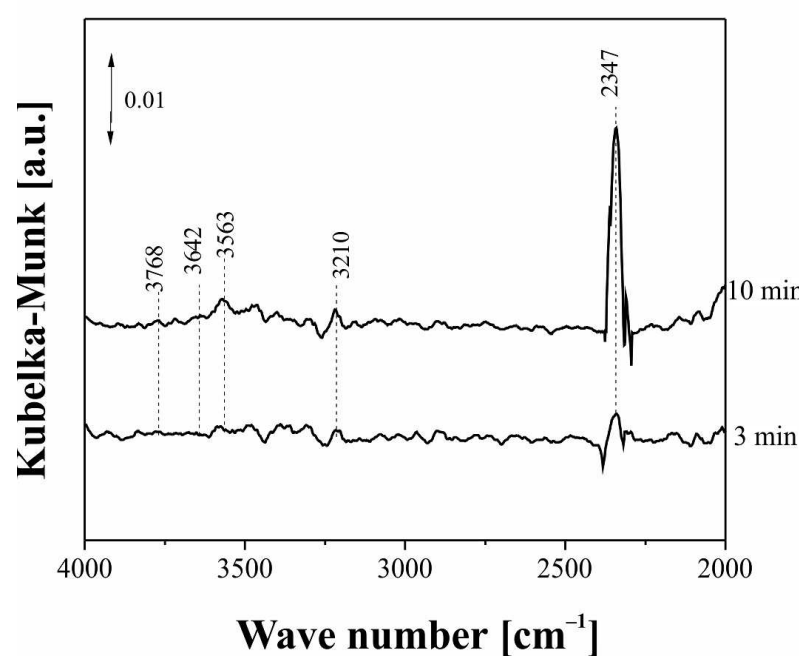

(a)

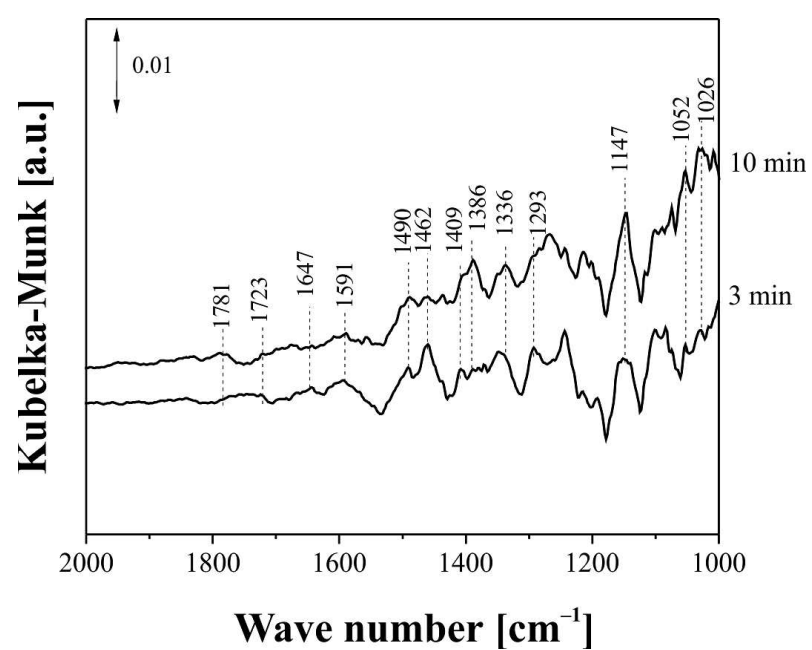

(b)

Fig. 5. DRFT-IR spectra of 200 ppm diethyl ether adsorption on an $\mathrm{SnO}_{2}$ film and thermal decomposition of ethyl ether at $380{ }^{\circ} \mathrm{C}$ : (a) $4000 \mathrm{~cm}^{-1}$ to $2000 \mathrm{~cm}^{-1}$, (b) $2000 \mathrm{~cm}^{-1}$ to $1000 \mathrm{~cm}^{-1}$.

intermediate products ethyl $\left(\mathrm{CH}_{3} \mathrm{CH}_{2} \bullet\right)$ and oxoethyl $\left(\mathrm{CH}_{3} \mathrm{CH}_{2} \mathrm{O} \cdot\right)$. And those at $v=$ $1409 \mathrm{~cm}^{-1}$ and $1293 \mathrm{~cm}^{-1}$ are deformation vibrations $\delta\left(\mathrm{CH}_{2}\right)$ and $\delta(\mathrm{CH})$ of ethylene $\left(\mathrm{C}_{2} \mathrm{H}_{4}\right)$ molecule. The absorption band at $v=1462 \mathrm{~cm}^{-1}$ is a $\mathrm{C}-\mathrm{CHO}$ stretching vibration $v(\mathrm{C}-\mathrm{CHO})$. That at $v=1147 \mathrm{~cm}^{-1}$ is a $\mathrm{C}-\mathrm{O}-\mathrm{C}$ stretching vibration $v(\mathrm{C}-\mathrm{O}-\mathrm{C})$ of diethyl ether. The absorption peak at $v=1052 \mathrm{~cm}^{-1}$ is a $\mathrm{C}-\mathrm{C}$ stretching vibration $v(\mathrm{C}-\mathrm{C})$. And that at $v=1026 \mathrm{~cm}^{-1}$ is $\mathrm{C}-\mathrm{O}$ stretching vibration $v(\mathrm{C}-\mathrm{O})$. New absorption peaks, compared to Fig. 4, that appear at $v=$ $1026 \mathrm{~cm}^{-1}$ comprise a $\mathrm{C}-\mathrm{O}$ stretching vibration $v(\mathrm{C}-\mathrm{O})$, at $v=3210 \mathrm{~cm}^{-1}$ and $1336 \mathrm{~cm}^{-1} \mathrm{OH}$ stretching vibration and deformation vibration $v(\mathrm{O}-\mathrm{H}), \delta(\mathrm{O}-\mathrm{H})$, respectively. The peaks at $v=$ $1386 \mathrm{~cm}^{-1}$ and $1336 \mathrm{~cm}^{-1}$ are the functional group $-\mathrm{CH}_{3}$ 's characteristic absorption of ethyl alcohol molecule.

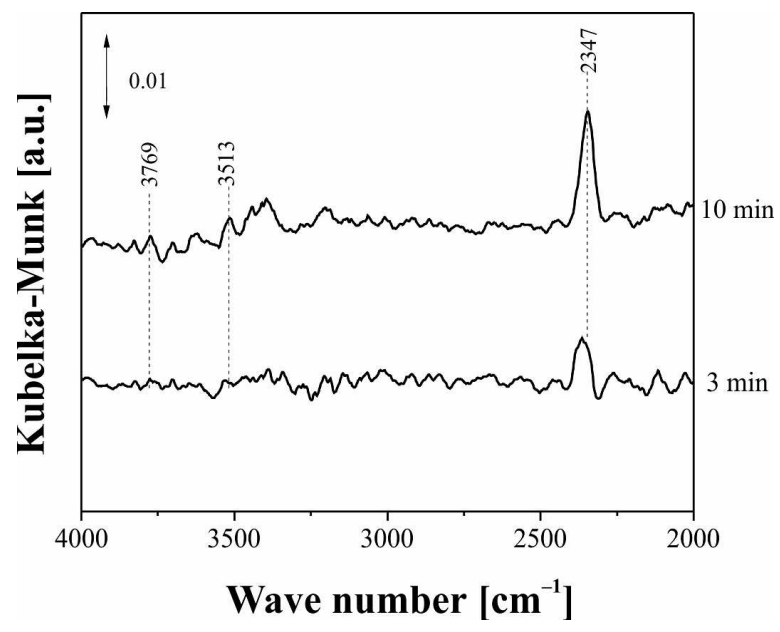

(a)

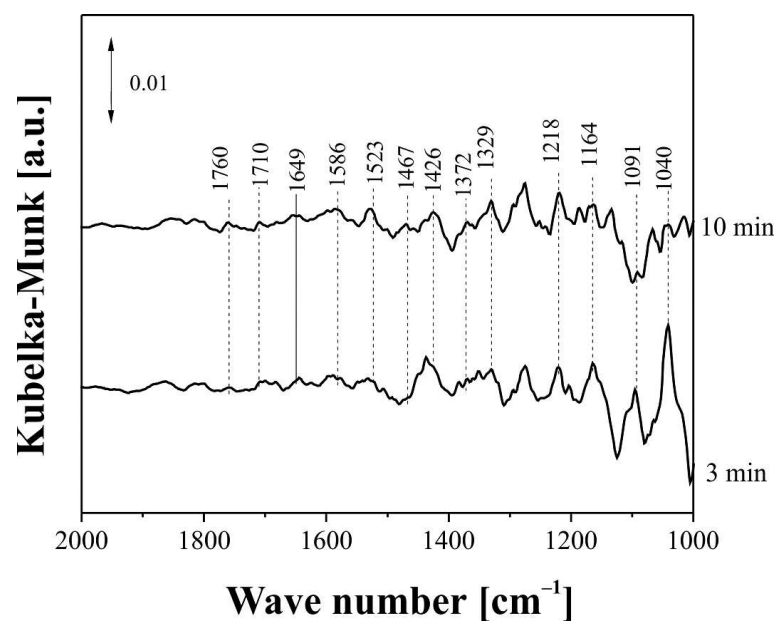

(b)

Fig. 6. DRFT-IR spectra of 200 ppm diethyl ether adsorption on an $\mathrm{SnO}_{2}$ film and thermal decomposition of ethyl ether at $400{ }^{\circ} \mathrm{C}$ : (a) $4000 \mathrm{~cm}^{-1}$ to $2000 \mathrm{~cm}^{-1}$, (b) $2000 \mathrm{~cm}^{-1}$ to $1000 \mathrm{~cm}^{-1}$.

Fig. 6 shows DRFT-IR spectra of 200 ppm diethyl ether adsorption on the $\mathrm{SnO}_{2}$ film and thermal decomposition of ethyl ether at $400{ }^{\circ} \mathrm{C}$. The bands at $v=3769 \mathrm{~cm}^{-1}$ and $3513 \mathrm{~cm}^{-1}$, 
$1586 \mathrm{~cm}^{-1}$ are the stretching and deformation vibrations of $\mathrm{H}_{2} \mathrm{O}$ molecule $v\left(\mathrm{H}_{2} \mathrm{O}\right)$ and $\delta\left(\mathrm{H}_{2} \mathrm{O}\right)$. That at $v=2347 \mathrm{~cm}^{-1}$ is a $\mathrm{CO}_{2}$ stretching vibration $v\left(\mathrm{CO}_{2}\right)$. The absorption peaks at $v=$ $1760 \mathrm{~cm}^{-1}, 1710 \mathrm{~cm}^{-1}$ are $\mathrm{C}=\mathrm{O}$ stretching vibration $v(\mathrm{C}=\mathrm{O})$ of aldehyde ( $\mathrm{HCHO}$ or $\left.\mathrm{CH}_{3} \mathrm{CHO}\right)$. That at $v=1649 \mathrm{~cm}^{-1}$ is $\mathrm{C}=\mathrm{C}$ stretching vibration $v(\mathrm{C}=\mathrm{C})$. And those at $v=1523 \mathrm{~cm}^{-1}$ and $1372 \mathrm{~cm}^{-1}$ are the $\mathrm{CH}_{2}, \mathrm{CH}_{3}$ deformation vibrations $\delta\left(\mathrm{CH}_{2}\right), \delta\left(\mathrm{CH}_{3}\right)$ of the intermediate products ethyl $\left(\mathrm{CH}_{3} \mathrm{CH}_{2} \bullet\right)$ and oxoethyl $\left(\mathrm{CH}_{3} \mathrm{CH}_{2} \mathrm{O} \bullet\right)$. The bands at $v=1467 \mathrm{~cm}^{-1}$ and $1218 \mathrm{~cm}^{-1}$ are deformation vibration $\delta\left(\mathrm{CH}_{2}\right)$ and $\delta(\mathrm{CH})$ of ethylene $\left(\mathrm{C}_{2} \mathrm{H}_{4}\right)$ molecule, these features can all be assigned to the intermediate product $\mathrm{C}_{2} \mathrm{H}_{4}$. That at $v=$ $1426 \mathrm{~cm}^{-1}$ is a $\mathrm{C}-\mathrm{CHO}$ stretching vibration $v(\mathrm{C}-\mathrm{CHO})$, and it indicates that $\mathrm{HCHO}$ and $\mathrm{CH}_{3} \mathrm{CHO}$ have been produced. And those at $v=1091 \mathrm{~cm}^{-1}$ and $1329 \mathrm{~cm}^{-1}$ are $\mathrm{C}-\mathrm{C}$ and $\mathrm{O}-\mathrm{H}$ stretching vibration and deformation vibration $v(\mathrm{C}-\mathrm{C})$ and $\delta(\mathrm{O}-\mathrm{H})$. The absorption peak at $v=1164 \mathrm{~cm}^{-1}$ is a $\mathrm{C}-\mathrm{O}-\mathrm{C}$ stretching vibration $\mathrm{v}(\mathrm{C}-\mathrm{O}-\mathrm{C})$ of diethyl ether. And that at $v=1040 \mathrm{~cm}^{-1}$ is a $\mathrm{C}-\mathrm{O}$ stretching vibration $v(\mathrm{C}-\mathrm{O})$.

A possible reaction mechanism of diethyl ether at $380{ }^{\circ} \mathrm{C}$ and $400{ }^{\circ} \mathrm{C}$ may be written using equation 5 to equation 12 as well as the following [54]:

$$
\begin{gathered}
\mathrm{CH}_{3} \mathrm{CH}_{2} \mathrm{OCH}_{2} \mathrm{CH}_{3}(\mathrm{ads})+\mathrm{SnO}_{2} \\
\rightarrow \mathrm{CH}_{3} \mathrm{CH}_{2} \mathrm{OH}+\mathrm{C}_{2} \mathrm{H}_{4}+\mathrm{SnO}_{2} \\
\mathrm{CH}_{3} \mathrm{CH}_{2} \mathrm{OH}+6 \mathrm{O}^{-} \rightarrow 3 \mathrm{H}_{2} \mathrm{O}+2 \mathrm{CO}_{2}+6 \mathrm{e}^{-}
\end{gathered}
$$

Fig. 7 shows DRFT-IR spectra of 200 ppm diethyl ether adsorption on the $\mathrm{SnO}_{2}$ film and thermal decomposition of ethyl ether after $10 \mathrm{~min}$ at different temperatures. From Fig. 7, it can be seen that the $\mathrm{CO}_{2}$ peaks at $380{ }^{\circ} \mathrm{C}$ are more intense than at $350{ }^{\circ} \mathrm{C}$ or $400{ }^{\circ} \mathrm{C}$, the absorption peak at $380{ }^{\circ} \mathrm{C}$ near $v=1026 \mathrm{~cm}^{-1}$, attributable to $(\mathrm{C}-\mathrm{O})$ of ethanol, is most intense at $380{ }^{\circ} \mathrm{C}$, implying more ethanol production at this temperature. The bands attributable to $(\mathrm{C}-\mathrm{C})$ of $\mathrm{CH}_{3} \mathrm{CH}_{2} \bullet$ and $\mathrm{CH}_{3} \mathrm{CH}_{2} \mathrm{O} \cdot$ are also more intense at $380{ }^{\circ} \mathrm{C}$ than at $350{ }^{\circ} \mathrm{C}$ or $400{ }^{\circ} \mathrm{C}$. This result is consistent with

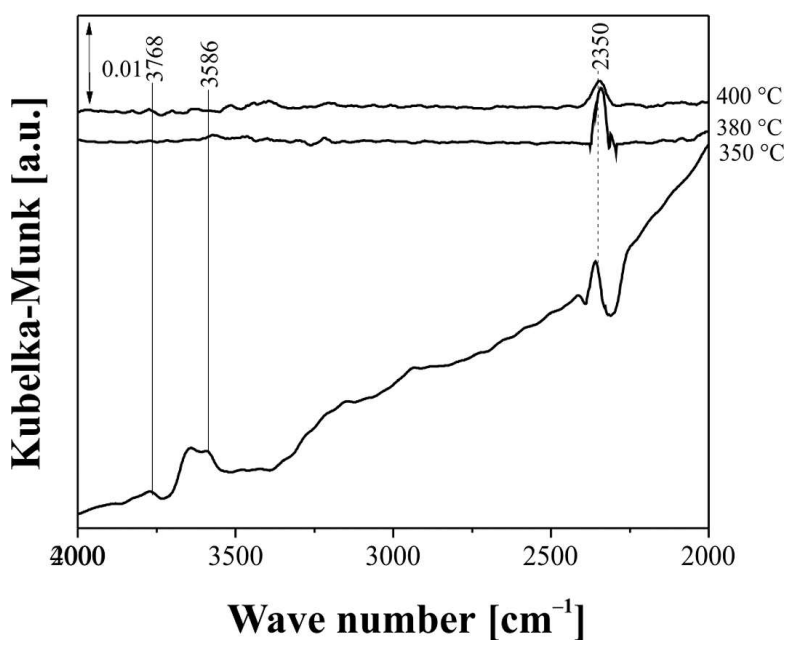

(a)

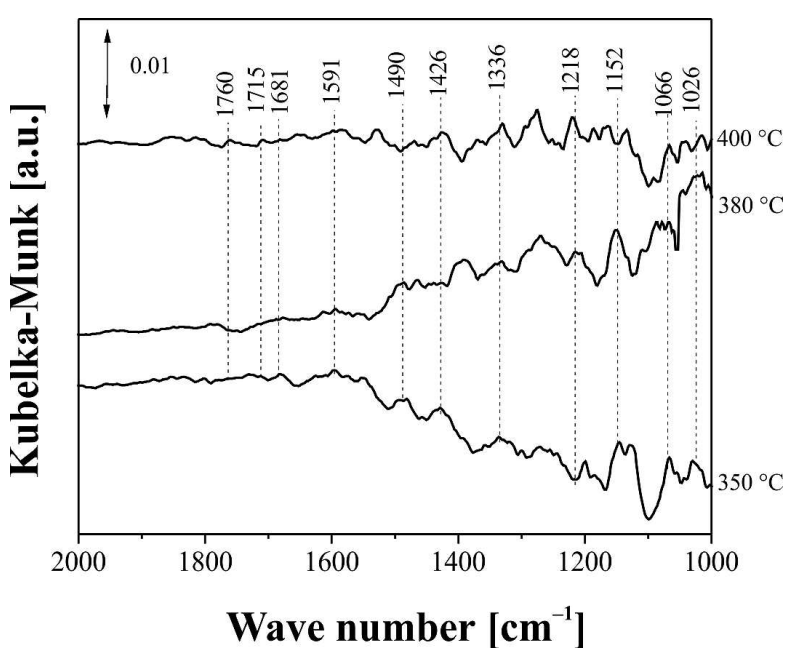

(b)

Fig. 7. DRFT-IR spectra of 200 ppm diethyl ether adsorption on an $\mathrm{SnO}_{2}$ film and thermal decomposition of ethyl ether after $10 \mathrm{~min}$ at different temperatures: (a) $4000 \mathrm{~cm}^{-1}$ to $2000 \mathrm{~cm}^{-1}$, (b) $2000 \mathrm{~cm}^{-1}$ to $1000 \mathrm{~cm}^{-1}$.

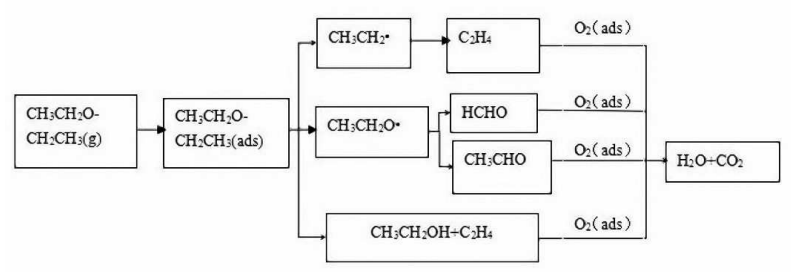

Fig. 8. Mechanism of diethyl ether adsorption and reactions on an $\mathrm{SnO}_{2}$ film including partial thermal decomposition of ethyl ether and oxidation of decomposition products. 
the change in the gas-sensing properties (Fig. 1), that is, the maximum amount of $\mathrm{CO}_{2}$ is produced at $380{ }^{\circ} \mathrm{C}$ due to maximum diethyl ether absorption, and the gas sensitivity at $380{ }^{\circ} \mathrm{C}$ is accordingly the highest.

Based on the products identified by the DRFTIR spectra under our experimental conditions (Fig. 4 to Fig. 6), we can speculate that when the $\mathrm{SnO}_{2}$ film was exposed to diethyl ether, the molecules were initially adsorbed on its surface. The absorbed diethyl ether molecules then decomposed and generated intermediate products $\mathrm{CH}_{3} \mathrm{CH}_{2} \bullet, \mathrm{CH}_{3} \mathrm{CH}_{2} \mathrm{O} \bullet, \mathrm{CH}_{3} \mathrm{CH}_{2} \mathrm{OH}$ and $\mathrm{C}_{2} \mathrm{H}_{4}$. These $\mathrm{CH}_{3} \mathrm{CH}_{2} \bullet$ and $\mathrm{CH}_{3} \mathrm{CH}_{2} \mathrm{O} \bullet$ reacted further to produce $\mathrm{C}_{2} \mathrm{H}_{4}, \mathrm{HCHO}$, and $\mathrm{CH}_{3} \mathrm{CHO}$. These intermediate products could further react with the oxygen anions on the surface generating $\mathrm{H}_{2} \mathrm{O}$ and $\mathrm{CO}_{2}$ as the reaction time increased from $3 \mathrm{~min}$ to $10 \mathrm{~min}$. Thus, a simplified reaction scheme of diethyl ether molecules on the $\mathrm{SnO}_{2}$ film including partial thermal decomposition of ethyl ether and the oxidation of decomposition products under our experimental conditions, as shown in Fig. 8, may be proposed. The reaction path is the same as that in literature reports $[9,33,54,55]$.

\section{Conclusions}

An $\mathrm{SnO}_{2}$ diethyl ether gas sensor has been successfully fabricated by a screen-printing technique based on $\mathrm{SnO}_{2}$ powder prepared by a solgel method. The gas sensitivity of the obtained $\mathrm{SnO}_{2}$ sensor to $1 \mathrm{ppm}$ and $200 \mathrm{ppm}$ diethyl ether reached 2.19 and 113.03 at $380{ }^{\circ} \mathrm{C}$, respectively. The results of DRFT-IR spectra revealed that ethyl $\left(\mathrm{CH}_{3} \mathrm{CH}_{2} \bullet\right)$, oxoethyl $\left(\mathrm{CH}_{3} \mathrm{CH}_{2} \mathrm{O} \bullet\right), \mathrm{CH}_{3} \mathrm{CH}_{2} \mathrm{OH}$, $\mathrm{HCHO}, \mathrm{CH}_{3} \mathrm{CHO}, \mathrm{C}_{2} \mathrm{H}_{4}, \mathrm{H}_{2} \mathrm{O}, \mathrm{CO}_{2}$, and molecularly adsorbed diethyl ether surface species were formed during the interaction of diethyl ether with the $\mathrm{SnO}_{2}$ film and thermal decomposition of ethyl ether at different temperatures. The mechanism of the reaction process may promote the development of improved gas sensors for diethyl ether, which may offer ultra-high detection capabilities for such organic molecules.

\section{Acknowledgements}

This work was supported by the Natural Science Foundation of Hubei Province, China (Grant No. 2014CFB1009), and the Opening Project (2015-KF-6) of the State Key Laboratory of Advanced Technology for Materials Synthesis and Processing (Wuhan University of Technology). The authors are also grateful to the Analytical and Testing Center of Huazhong University of Science and Technology.

\section{References}

[1] Chen G.Q., Wu Y.M., Zhu T., Zhang Y.Z., J. Atom. Mol. Phys., 24 (2007), 101 (in Chinese).

[2] Rakopoulos D.C., Rakopoulos C.D., Giakoumis E.G., Dimaratos A.M., Energy, 43 (2012), 214.

[3] BaI C.H., Zhang B., XIU G.L., LiU Q.M., CHEN M., Fuel, 107 (2013), 400.

[4] Yuan X.L., XIE C.S., Yang L., Zhang S.P., Sensor. Actuat. B-Chem., 195 (2014), 439.

[5] LiU J.Q., Zhang Y.T., Yuan Y.F., Zuo W.W., Acta Chim. Sinica, 71 (2013), 102.

[6] CAO X.P., Forensic Sci. Technol., 4 (1981), 66 (in Chinese).

[7] Wang J., Dong C.R., Chinese J. Practical Int. Med., 3 (1983), 252 (in Chinese).

[8] Scotter M.J., Roberts D.P.T., J. Chromatogr. A, 1157 (2007), 386.

[9] Hu J., Xu K.L., Jia Y.Z., Lv Y., Li Y.B., Hou X.D., Anal. Chem., 80 (2008), 7964.

[10] Lin H.B., SHI J.S., Sensor. Actuat. B-Chem., 92 (2003), 243.

[11] CAO X.A., Chen Z.H., Wang Y.L., J. Guangzhou Uni. Nat. Sci. Ed., 9 (2010), 28 (in Chinese).

[12] Cao X.A., Wu W.F., Chen N., Peng Y., LiU Y.H., Sensor. Actuat. B-Chem., 137 (2009), 83.

[13] Volanti D.P., FeliX A.A., ORlandi M.O., WhitFIEld G., YANG D.J., LONGo E., Tuller H.L., VAREla J.A., Adv. Funct. Mater., 23 (2013), 1759.

[14] Xie C.S., XiaO L.Q., Hu M.L., Bai Z.K., Xia X.P., ZENG D.W., Sensor. Actuat. B-Chem., 145 (2010), 457.

[15] Li Y., Hsu P.C., Chen S.M., Sensor. Actuat. B-Chem., 2012, 174 (2012), 427.

[16] Ohgaki T., Matsuoka R., Watanabe K., Sensor. Actuat. B-Chem., 150 (2010), 99.

[17] LiU S.Q., XIE M.J., Li Y.X., GuO X.F., Ji W.J., Ding W.P., Sensor. Actuat. B-Chem., 151 (2010), 229.

[18] He L.F. He, Guo Z., Chen X., Meng F.L., Luo T., Li M.Q., LiU J.H., J. Phys. Chem. C, 113 (2009), 9581.

[19] Wang D., Chu X.F., Gong M.L., Sensor. Actuat. BChem., 117 (2006), 183.

[20] Hyodo T., Abe S., Shimizu Y., Egashira M., Sensor. Actuat. B-Chem., 93(2003), 590.

[21] Huang J., Matsunaga N., Shimanoe K., YamaZOE N., Kunitake T., Chem. Mater., 17 (2005), 3513.

[22] Wang P.J., YaO B.H., Wei Q.B., Zhang Y.Q., XUE H.F., Chem. Bioeng., 29 (2012), 21 (in Chinese). 
[23] REN Y.F., J. Chinese Soc. Rare Earth, 3 (1985), 15 (in Chinese).

[24] Slobodian P., Riha P., Lengalova A., SvoBODA P., SAHA P., Carbon, 49 (2011), 2499.

[25] Ma X.D., Guo H., Guo X., Lv L., He X., Feng X., Chem. J. Chinese U., 33 (2012), 1915.

[26] ZhaO W., Zhang Z.Y., WU T.Z., WANG X.W., Deng Z.H., DAI K., Electron. Comp. Mater, 24 (2005), 36 (in Chinese).

[27] Aizawa H., Noda K., Naganawa R., Yamada K., Yoshimoto M., Reddy S. M., Kurosawa S., $J$. Photopolym. Sci. Tec., 22 (2009), 743.

[28] Gui Y.H., Cui R.L., NiU L.J., Conserv. Util. Miner. Resour, 6 (2009), 32 (in Chinese).

[29] Huang K.J., Zhang Z. X., Yuan F. L., Xie C. S., Curr. Nanosci., 9 (2013), 357.

[30] WANG X. J., Zhang S. P., Zhang G. Z., Electron. Technol., 39 (2012), 53 (in Chinese).

[31] Zhang H., Feng J. C., Fei T., LiU S., Zhang T., Sensor. Actuat. B-Chem., 190 (2014), 472.

[32] Zhang Z.X., Huang K.J., Yuan F.L., XIE C. S., J. Mater. Res., 29 (2014), 139.

[33] LiU X.M., Zhang Q., Ito S., Wada Y., Fuel, 165 (2016), 513.

[34] Yin L., Chen D. L., Cui X., Ge L. F., Yang J., Yu L.L., Zhang B., ZhANG R., SHAO G. S., Nanoscale., 6 (2014), 13690.

[35] Lee S. K., Chang D., Kim S.W., J. Hazard. Mater, 268 (2014), 110.

[36] Suchorska-Wozniak P., RaC O., Fiedot M., Teteryez H., Sensors-Basel, 14 (2014), 20480.

[37] Zhang Z.Y., Zou R.J., Song G.S., Yu L., Chen Z. G., HU J.Q., J. Mater. Chem., 21 (2011), 17360.

[38] Grossmann K., Pavelko G.R., Barsan N., Sensor. Actuat. B-Chem., 166 (2012), 787.

[39] Yokosuka Y., Oki K., Nishikiori H., Res. Chem. Intermediat., 35 (2009), 43.
[40] Jang M., McDow S.R., Environ. Sci. Technol., 31 (1997), 1046.

[41] Huang S.Y., Zhang C.B., He H., Catal. Today, 139 (2008), 15.

[42] HU J.H., Zheng X.F., Practical Infrared Spectroscopy, Science Press, Beijing, 2011 (in Chinese).

[43] FEng J.C., Structural Analysis and Identification of Organic Compounds, National Defence Industry Press, Beijing, 2003 (in Chinese).

[44] Weng S.F., Fourier Transform Infrared Spectrum Analysis, Chemical Industry Press, Beijing, 2010 (in Chinese).

[45] Kecskes T., Rasko J., Kiss J., Appl. Catal. A-Gen., 273 (2004), 55.

[46] XU W.Z., Raftery D.S.J., J. Phys. Chem. B, 107 (2003), 4537.

[47] Du X., Du Y., George S.M., J. Phys. Chem. A, 112 (2008), 9211.

[48] Millar J.G., Colin H., Rochester H.C., J. Catal., 155 (1995), 52.

[49] HE Y.B., Ji H.B., Chinese J. Catal., 31 (2010), 171.

[50] Driessen M.D., Goodman A.L., Miller T.M., $J$. Phys. Chem. B, 102 (1998), 549.

[51] Fan J.F., John T.Y., J. Am. Chem. Soc., 118 (1996), 4686.

[52] Kim J.S., Itoh K., Murabayashi M., Chemosphere, 36 (1998), 483.

[53] Rasko J., Kecskes T., Kiss J., J. Catal., 226 (2004), 183.

[54] Yasunaga K., Gillespie F., Simmie J.M., Curran H.J., Kuraguchi Y., Hoshikawa H., Yamane M., Hidaka Y., J. Phys. Chem. A, 114 (2010), 9098.

[55] Farkas A.P., Solymosi F., Surf. Sci., 602 (2008), 1497.

Received 2016-04-22 Accepted 2017-02-05 